\title{
Comparative technology assessment of anaerobic digestion of organic fraction of MSW
}

\author{
A. Cesaro, V. Belgiorno \& V. Naddeo \\ Sanitary Environmental Engineering Division (SEED), \\ Department of Civil Engineering, \\ University of Salerno via Ponte Don Melillo, Fisciano (SA), Italy
}

\begin{abstract}
Anaerobic digestion is the biological degradation process of organic matter under anoxic conditions, with production of methane and inorganic by-products, including carbon dioxide. Over the past years, many studies on anaerobic digestion of the organic fraction of municipal solid waste (OFMSW) have been carried out at laboratory, bench and pilot scale. This work aims to summarize the main features of the OFMSW anaerobic digestion techniques and to define the state of art of this process in Europe, at both research and industrial level. To this end, main experimental results, design solutions and technologies are compared, also in relation to capital and operating costs and data about full scale experiences are reported. Among the different aspects discussed, particular interest has been provided to pretreatment possibilities in relation to substrate biodegradability and biogas production rate. The data collected and examined in this paper stress the aspects to be improved, in order to define future perspectives of the anaerobic process application for OFMSW treatment.
\end{abstract}

Keywords: anaerobic digestion, organic fraction of municipal solid waste, pretreatment.

\section{Introduction}

The need to avoid direct landfilling of biodegradable residues is shared by the whole technical community. In the European Union this statement has been recognized since the promulgation of the Council Directive 1999/31/EC on waste landfilling which, as part of the measures undertaken to improve the sustainability of waste management, forced member states to reduce the amount 
of biodegradable fractions contained in municipal solid waste (MSW) destined to sanitary landfill [1].

Coherently with the above mentioned concept, biological treatments are the main alternative for the organic fraction of municipal solid waste (OFMSW) [2].

Anaerobic digestion, defined as the biological degradation process of organic matter under anoxic conditions, could be a suitable choice for the biodegradable fraction of urban solid waste. The interest in this treatment is mainly due to the production of methane, which can be used as a renewable energy source in front of aerobic stabilization that requires energy consumption.

The utilization of methane gas as a renewable energy from the biomass anaerobic digestion can be used to obtain certified emission reduction (CER) credits by clean development mechanism (CDM) under the Kyoto Protocol [3].

Over the past years, many studies on anaerobic digestion of OFMSW have been carried out at laboratory, bench and pilot scale. The organic wastes used in previous studies include: market waste [4], fruit and vegetable waste [5], kitchen waste [6], biowaste [7] mechanically sorted [8] and source sorted [9] organic fraction of municipal solid waste. Factors influencing the process stability and efficiency have also been investigated.

This work aims to summarize the main features of the OFMSW anaerobic digestion techniques and to define the state of art of this process in Europe, at both research and industrial level. To this end, main experimental results, design solutions and technologies are compared, also in relation to capital and operating costs and data about full scale experiences are reported. Among the different aspects discussed, particular interest has been provided to pretreatment possibilities in relation to substrate biodegradability and biogas production rate.

The data collected and examined in this paper stress the aspects to be improved, in order to define future perspectives of the anaerobic process application for OFMSW treatment.

\section{Pretreatment to anaerobic digestion}

Pretreatment is a fundamental step, useful to improve anaerobic digestion yields, operating on the substrate characteristics. Literature data reports experiences dealing with chemical, biological and physical processes (Table 1) that are intended to increase the efficiency of the hydrolysis, which is recognized as the rate limiting step in anaerobic digestion processes [10].

Table 1: $\quad$ Pretreatments to anaerobic digestion.

\begin{tabular}{|c|c|c|}
\hline Kind of pretreatment & Objective & Mechanism \\
\hline Chemical & $\begin{array}{c}\text { Improve } \\
\text { biodegradability of } \\
\text { complex organic } \\
\text { Physical }\end{array}$ & $\begin{array}{c}\text { Thermal/Mechanical } \\
\text { processes }\end{array}$ \\
\cline { 1 - 1 } Biological & matter & Enzymatic processes \\
\hline
\end{tabular}


Even though a large number of pretreatments have been investigated, there are very few reports in literature dealing with the possible treatment of the OFMSW prior to anaerobic digestion.

The main chemical processes are the oxidation with wet air and the ozonation, but there are studies dealing with peroxidation methods prior to biosolid anaerobic digestion [11]. Fox and Noike [12] studied wet oxidation for the increase in anaerobic biodegradability of newspaper waste: they found the highest methane conversion efficiency for newspaper pretreated at $190^{\circ} \mathrm{C}$, with anaerobic cellulose removals ranging between 74 and $88 \%$.

In the last years, the use of ozone in chemical pretreatment is gaining great interest in the scientific community, not only by removing recalcitrant and toxic compound but also by increasing the biodegradability of waste [10, 13]. Many authors also reported the anaerobic digestion enhance after an alkaline pretreatment. López Torres and Espinosa Llórens [10] demonstrated the increased OFMSW anaerobic digestion efficiency after an alkaline pre-treatment with $\mathrm{Ca}(\mathrm{OH})_{2}$.

Since hydrolysis is carried out by extracellular enzymes, some authors investigated the addition of hydrolytic enzymes as a pretreatment to increase the yield and the rate of particulate matter solubilisation during anaerobic digestion. Valladão et al. [14] studied enzymatic pretreatment effects on poultry slaughterhouse effluent anaerobic treatment and he pointed out the enhance of raw effluent anaerobic treatment efficiency when a $0,1 \%$ concentration of enzymatic pool was used in the pre-hydrolysis stage with $1.200 \mathrm{mg} / \mathrm{L}$ oil and grease.

Among the physical pretreatments, both mechanical and thermal ones have to be listed. Besides shredding and pulping, which are usually applied to solid waste in order to reduce their particle size, mechanical pretreatment include the use of high pressure gradients to rupture cell walls, but they have been investigated only in relation to sludge, as well as heat treatments [15]. Often thermal pretreatments are combined with alkaline ones. Carrère et al. [16] compared thermal and thermo-chemical treatments prior to pig manure anaerobic digestion.

More recent techniques use ultrasound (US) process to pretreat organic matter to be digested [17]. Chen et al. [18] investigated ultrasound process effects on hydrolysis and acidogenesis of solid organic wastes, founding out improved performances.

\section{Anaerobic digestion technologies}

In relation to the total solid (TS) content fed to the digester, anaerobic digestion (AD) technologies are divided in:

- wet digestion, when the TS $<10 \%$;

- dry digestion, if the TS $>25 \%$

- $\quad$ semi-dry digestion, if the TS content ranges between 10 and 25\% [19].

More than $87 \%$ of the digestion capacity is provided by single-phase digesters, which can use wet or dry technologies. A slight increase of wet 
systems was observed as a number of large-scale wet plants were put into operation in Netherland and Spain in 2003 and 2004, while more dry fermentation plants were constructed in 2005. In 2006, De Baere [20] found that dry anaerobic fermentation provides $56 \%$ capacity while wet fermentation is used in $44 \%$ of the total installed capacity, but according to Schievano et al. [21], the wet processes are currently the most spread.

The list of $\mathrm{AD}$ processes and suppliers is highly variable as a result of acquisition, merges and technology advances: the main ones are listed in Table 2 .

Table 2: $\quad$ Main AD technology suppliers [22].

\begin{tabular}{|c|c|c|c|}
\hline Supplier & Process & Technology & $\begin{array}{c}\text { Capacity range } \\
{[\mathrm{t} / \mathrm{y}]}\end{array}$ \\
\hline Arrow Ecology & Arrow Bio & wet & $90.000-180.000$ \\
\hline $\begin{array}{c}\text { BTA International } \\
\text { GmbH }\end{array}$ & BTA & wet & $1.000-150.000$ \\
\hline Citec & Waasa & wet & $3.000-230.000$ \\
\hline Ros Roca International & Biostab & wet & $10.000-150.000$ \\
\hline Organic Waste Systems & Dranco & dry & $3.000-120.000$ \\
\hline Haase & MBT & wet & $50.000-200.000$ \\
\hline $\begin{array}{c}\text { Farmatic Biotech } \\
\text { Energy AG }\end{array}$ & $\begin{array}{c}\text { Schwarting - } \\
\text { Uhde }\end{array}$ & wet & $18.000-200.000$ \\
\hline Valorga International & Valorga & dry & $10.000-497.600$ \\
\hline Kompogas & Kompogas & dry & $5.000-100.000$ \\
\hline $\begin{array}{c}\text { Strabag (formerly } \\
\text { Linde) }\end{array}$ & $\begin{array}{c}\text { Linde - } \\
\text { KCA/BRV }\end{array}$ & wet/dry & $6.000-150.000$ \\
\hline Entec & Entec & wet & $40.000-150.000$ \\
\hline Wehlre-Werk AG & Biopercolat & dry & 100.000 \\
\hline Global Renewables Ltd & ISKA & dry & $88.000-165.000$ \\
\hline
\end{tabular}

In the following paragraphs, data about some of these technologies are given and compared.

\subsection{Wet digestion}

Wet system appears attractive because of its similarity to the consolidate technology in use for the anaerobic stabilization of sewage sludge coming from wastewater treatment. The operational simplicity is the main reason why this technology is adopted in the majority of plants with capacity lower than $100.000 \mathrm{t} / \mathrm{y}$ [22]. In wet system the organic solid waste is diluted to less than $10 \%$ TS, adding water or recirculating part of the digester effluent. Consequently, CSTR (continuously stirred tank reactor) digesters are mostly used in these applications [19, 23].

Wet processes usually work with low organic loading rate (OLR), ranging between 2 and $4 \mathrm{~kg}_{\mathrm{VS}} / \mathrm{m}^{3} \mathrm{~d}$. Currently, it is still unclear what is the phenomenon 
that limits the possibility of applying higher organic loads in wet processes. One possible explanation is the concentration of active biomass in the reactor, which could be not high enough. According to other studies, the reason is the nutrient mass transfer rate or the accumulation of inhibitory substances such as ammonia or short-chain volatile fatty acids. Anyway, possible problems could be easily solved adding water in order to improve dilution. Table 3 summarizes the typical values of the main single-stage wet anaerobic process parameters.

Table 3: Design parameters and process yields of an AD wet system.

\begin{tabular}{|c|c|}
\hline Parameter & Value \\
\hline Total Solid (TS) content [\%] & $<10$, until 15 \\
\hline Organic Loading Rate $\left[\mathrm{kg}_{\mathrm{VS}} / \mathrm{m}^{3} \mathrm{~d}\right]$ & $2-4$, until 6 \\
\hline Hydraulic Retention Time [d] & $10-15$, until 30 \\
\hline \multicolumn{2}{|l|}{ Process yields } \\
\hline Biogas production $\left[\mathrm{m}^{3} / \mathrm{t}_{\text {waste }}\right]$ & $100-150$ \\
\hline Specific biogas production $\left[\mathrm{m}^{3} / \mathrm{kg} \mathrm{sv}\right]$ & $0,4-0,5$ \\
\hline Biogas production rate $\left[\mathrm{m}^{3} / \mathrm{m}^{3} \mathrm{~d}\right]$ & $5-6$ \\
\hline Methane content $[\%]$ & $50-70$ \\
\hline Volatile solid (VS) reduction rate [\%] & 50-60, until 75 \\
\hline
\end{tabular}

Waasa process is implemented in several Finnish plants [23], with operative capacity ranging from 3.000-85.000 t/y. A pulper with three vertical auger mixers is used to shred, homogenize and dilute the wastes in sequential batches. The obtained slurry is then digested in large complete mixed reactors where the solids are kept in suspension by vertical impellers. Gas production ranges between 170 and $320 \mathrm{Nm}^{3}{ }_{\mathrm{CH} 4} / \mathrm{t}_{\mathrm{VS}-\text { fed }}$ and reduction of the volatile solid (VS) feed varies between $40-75 \%$ [24].

Wabio technology was supplied in Berlin plant, which treats source sorted wastes with $18-25 \%$ TS then diluted till $10-15 \%$ TS. The reactor works in mesophilic conditions, with an OLR ranging between 3 and $7 \mathrm{~kg}_{\mathrm{TVS}} / \mathrm{m}^{3} \mathrm{~d}$ and a hydraulic retention time (HRT) of 15-17 days. The biogas production ranges between $100-150 \mathrm{~m}^{3} / \mathrm{t}$, with methane $\left(\mathrm{CH}_{4}\right)$ content varying between 50 and $70 \%$.

Another system quite common in Europe is the Bio-Stab one that was developed from ATU Ingenieurgesellschft für Abfalltechnik und Umweltschutz. This process is a wet digestion technology which makes possible the separation of impurities before the biological treatment by means of mechanical separation without hand-sorting. Due to the very effective separation of the impurities, the digestate has high-quality and is characterized by a low salt and a high organic content. The biogas produced by the digestion is energetically used for the operation of the digestion plant [25].

The BTA process is applicable both in one stage and two stage AD systems. Pilot and industrial scale experiences demonstrate that BTA process can treat waste with different characteristics, with a moisture content varying between 
$60 \%$ and $90-98 \%$, and a biodegradable matter content ranging between $2 \%$ and $50 \%[26]$.

In the United Kingdom, one of the established technologies is provided by Monsal company that exclusively uses wet AD processes. For MSW treatment their process requires a pre-sorting stage to separate the organic fraction from the bulk of the non-organic materials. Monsal have delivered over 220 anaerobic digestion systems in the last 14 years, supplying digestion technologies to plants ranging from 2.000 to $88.000 \mathrm{~m}^{3}$ capacity [27]. The company also provides advanced anaerobic digestion systems, which include biological hydrolysis. Bungay [28] discussed three variants of advanced anaerobic digestion using biological hydrolysis and points out its sustainability benefits when compared with more energy intensive thermal hydrolysis processes.

\subsection{Dry digestion}

During the 80 's research demonstrated that biogas yield and production rate were higher in systems where the wastes were kept without diluted water, in their original solid state [29].

In dry systems, the fermenting mass within the reactor is characterised by solids content in the range $20-40 \%$ TS: therefore, only dry substrates with TS > $50 \%$ need to be diluted.

The most applied technologies for dry process are Dranco, Valorga and Kompogas, all working in the range $30-40 \%$ of TS in the reactor feeding [30].

In Dranco process, the mixing occurs via recirculation of the waste extracted at the bottom, mixed with fresh wastes (one part fresh wastes for six parts digested wastes) and pumped to the top of the reactor. This simple design is suitable for the treatment of waste ranging from 20 to $50 \%$ TS $[23,31]$. Table 4 reports operational parameters and yields of Salzburg (Austria) and Brecht (Belgium) plants implementing Dranco process.

Table 4: Operational parameters and yield of Salzburg (Austria) and Brecht (Belgium) plants.

\begin{tabular}{|c|c|c|}
\hline Parameter & Salzburg (Austria) & Brecht (Belgium) \\
\hline Capacity [t/y] & 20.000 & 20.049 \\
\hline Total Solid content [\%TS] & 31 & 40 \\
\hline Temperature $\left[{ }^{\circ} \mathrm{C}\right]$ & 55 & 55 \\
\hline Organic Loading Rate $\left[\mathrm{kg}_{\mathrm{vS}} / \mathrm{m}^{3} \mathrm{~d}\right]$ & 10 & 14.9 \\
\hline Specific Gas Production $\left[\mathrm{m}^{3} / \mathrm{kg}_{\mathrm{vs}}\right]$ & 0.36 & $0.25-0.30$ \\
\hline Gas Production Rate $\left[\mathrm{m}^{3} / \mathrm{m}^{3} \mathrm{~d}\right]$ & 4 & 9.2 \\
\hline Volatile Solid removal $[\% \mathrm{sv}]$ & 29 & 23 \\
\hline
\end{tabular}

Kompogas process works similarly to the Dranco one, but the plug flow takes place horizontally, in cylindrical reactors. The horizontal plug flow is aided by slowly-rotating impellers inside the reactors, which also serve for homogenization, degassing, and resuspension of heavier particles. This system 
requires careful adjustment of the solid content around 23\% TS inside the reactor. At lower values, heavy particles such as sand and glass tend to sink and accumulate inside the reactor while higher TS values cause excessive resistance to the flow $[23,31]$.

The digestion plant in Braunschweig-Watenbuttel (Germany), implementing Kompogas process, treats $20.000 \mathrm{t} / \mathrm{y}$ of source sorted organic waste. Process yield in terms of biogas production is $80-140 \mathrm{~m}^{3}$ with $60 \%$ of $\mathrm{CH}_{4}$ per ton of biomass fed while the volatile solid reduction content ranges between $47-52 \%$ [32].

The biogas plant in Roppen, Tyrol (Austria) was designed to process 10.000 $\mathrm{t} / \mathrm{y}$ of catering waste (mostly in the touristic peak time, in winter and summer) and kitchen and garden waste from households with the Kompogas technology.

After pretreatment, the waste is fermented in a tube-digester, without the addition of water, at thermophilic temperature $\left(45-60^{\circ} \mathrm{C}\right)$. The fermentation end product is separated into a solid and a liquid phase. The former is further stabilized aerobically; the latter is used for moisturising during the aerobic stabilization process of additional organic wastes or optionally used as liquid fertilizer [33].

In Switzerland, Kompogas technology is the most implemented for the anaerobic treatment of organic waste. For some of the oldest plants, operation data are given [34], together with biogas production yields. Table 5 reports the available information and shows that Volketswil plant is overloaded, since the estimated organic loading rate is $17 \mathrm{~kg}$ organic material $/ \mathrm{m}^{3} \mathrm{~d}$.

Table 5: $\quad$ Kompogas anaerobic digestion plants in Switzerland [34].

\begin{tabular}{|c|c|c|c|c|}
\hline Location & $\begin{array}{c}\text { Volume } \\
{\left[\mathrm{m}^{3}\right]}\end{array}$ & $\begin{array}{c}\text { Treated waste } \\
{[\mathrm{t} / \mathrm{y}]}\end{array}$ & $\begin{array}{c}\text { Gas yields } \\
{\left[\mathrm{m}^{3} / \mathrm{y}\right]}\end{array}$ & $\begin{array}{c}\text { Energy } \\
{[\mathrm{MWh} / \mathrm{y}]}\end{array}$ \\
\hline Bachenbülach & $812(3)$ & 13.577 & 1.565 .361 & 9.079 \\
\hline Otelfingen & $780(1)$ & 13.814 & 1.639 .904 & 9.511 \\
\hline Samstagern & $512(2)$ & 9.377 & 893.944 & 5.185 \\
\hline Volketswil & $290(1)$ & $\sim 7.500$ & 461.000 & 2.674 \\
\hline
\end{tabular}

Today, Kompogas has developed a new generation of plants with annual treating capacity ranging from 4.000 to $20.000 \mathrm{t} / \mathrm{y}$. Outside Switzerland, also larger plants have been built. The waste is delivered at ground level inside a hall and the reactor is heated by lignified fraction withheld by the sieve while working up the waste: this procedure increases the usable gas share.

Besides Kompogas, Swiss industrial digestion plants operate with BRV-Linde and Valorga technologies.

BRV-Linde system was implemented in 1994, in Baar anaerobic digestion plant. It is a thermophilic horizontal plug flow digester, with a working volume of $500 \mathrm{~m}^{3}$. Since the horizontal cylinder was protected by a patent of Kompogas, the BRV reactor was built with a rectangular cross section. This shape has the disadvantage that it is not possible to stir the content with a longitudinal axis equipped with lateral arms, so it had to be managed with four transversal axis. 
This system causes a mixing for and backwards in flow direction, hampering the ideal plug flow of the substrate [34].

In Valorga system the horizontal plug flow is circular and mixing occurs via biogas injection at high pressure at the bottom of the reactor every 15 minutes [35]. However, differences among dry systems are more significant in term of sustainable OLR. The Valorga plant at Tilburb (the Netherlands) treats quantities of waste that vary from 400 and $1.100 \mathrm{t} /$ week in two digesters of $3.300 \mathrm{~m}^{3}$ each at $40{ }^{\circ} \mathrm{C}$ (Fruteau de Laclos et al. [35]). This corresponds to an OLR of 5 $\mathrm{Kg}_{\mathrm{vs}} / \mathrm{m}^{3} \mathrm{~d}$ that is comparable to the design values of plants relying on wet system. Optimized dry system may sustain higher OLR such as the Dranco plant in Brecht (Belgium) that works with OLR of $15 \mathrm{Kg}_{\mathrm{vs}} / \mathrm{m}^{3} \mathrm{~d}$ [20]. This value is achieved without any dilution of the wastes and corresponds to a retention time of 14 days during the summer with $65 \%$ VS destruction. Typical design OLR values of the Dranco process are however more conservative (about 12 $\mathrm{Kg}_{\mathrm{Vs}} / \mathrm{m}^{3} \mathrm{~d}$ ) but higher than the wet systems ones. As a consequence, at equal capacity, the reactor volume of a Dranco plant is smaller than that of a wet system [20].

\section{Technical and economical comparison}

High-solid processes appear to be more efficient at higher loaded process (OLR $>6 \mathrm{~kg} \mathrm{vS}_{\mathrm{v}} / \mathrm{m}^{3} \mathrm{~d}$ ) while low solid processes are more beneficial at OLR lower then $6 \mathrm{~kg} \mathrm{vs}_{\mathrm{v}} / \mathrm{m}^{3} \mathrm{~d}$. Furthermore, wet digestion processes require a relatively high cost for process equipment and the quantity of process water is appreciably greater than for dry digestion processes: while wet systems typically consume 1 $\mathrm{m}^{3}$ of fresh water per ton of treated OFMSW, dry systems require water volumes about ten times lower. As a consequence, the volume of wastewater to be discharged is several times smaller for dry systems. For this reason, when wet systems are implemented, it becomes important to have a wastewater treatment plant nearby.

The maximum achievable OLR, however, is highly dependent on reactor configuration. An upper limit on OLR seems to exist at around $15 \mathrm{~kg} \mathrm{vs}_{\mathrm{s}} / \mathrm{m}^{3}$, but the achievable OLR can be greatly affected by the overall digestibility of the waste. With reference to the biogas or methane production rate, comparing the performance of industrial scale OFMSW digesters treating different waste streams is difficult, especially since companies tend to protect performance data. Generalizations have been attempted in literature: Figure 1 shows the average biogas yield at a given OLR for a large number of lab, pilot, and full scale studies [36].

Even though the mesophilic digestion of food waste achieved a biogas yield of about $0.8 \mathrm{~m}^{3} / \mathrm{kg}_{\mathrm{vS}}$, the OLR was only $2 \mathrm{~kg} \mathrm{vs} / \mathrm{m}^{3} \mathrm{~d}$. For comparison, wet digestion of source sorted organic fraction of municipal solid waste (SSOFMSW) at $55^{\circ} \mathrm{C}$ resulted in much lower biogas yields of 0.45 and $0.3 \mathrm{~m}^{3} / \mathrm{kg}_{\mathrm{vs}}$, but at OLR of 6 and $9 \mathrm{~kg}_{\mathrm{vs}} / \mathrm{m}^{3} \mathrm{~d}$. Based on this analysis, most of the reactors studied exhibited biogas production rates in the range of $1.5-3.5 \mathrm{~m}^{3} / \mathrm{m}^{3} \mathrm{~d}$. 


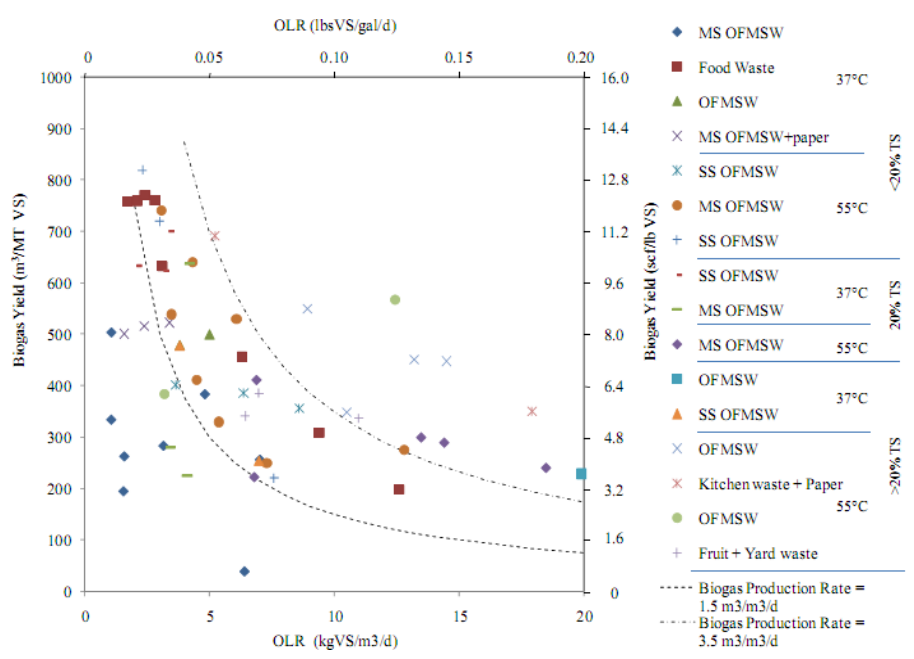

Figure 1: Biogas yields in function of organic loading rate [36].

As regards the economical aspect, according to Confalonieri [37], capital costs range between 400 and $800 € /$ ton/year of installed capacity. Economy of scale strongly affects capital costs and usually the lower values characterize larger plants $(>50.000-70.000 \mathrm{t} / \mathrm{y})$.

The economical differences between wet and dry systems are small, both in terms of capital and operating costs. The higher costs for the waste handling devices such as pumps, screws and valves required for dry systems are balanced by a cheaper pretreatment and reactor, the latter being several times smaller than for wet systems.

Reliable financial information on the performance of the many competing AD technologies is hard to come by; the report of the California Integrated Waste Management Board [36] concluded that discussions of the cost of anaerobic digestion were severely constrained by the lack of real information. Despite the difficulties, data about capital and operating costs were elaborated in two different studies. Although separated by 10 years, the capital cost curves from these studies are very similar, while operating costs are not: however, differences could be due to differences in the cost items included in the two works.

\section{Future perspectives}

At present, anaerobic digestion is considered a well-known and reliable technology for OFMSW treatment. The most interesting aspect of this process is the production of biogas, which is a clean and environmentally friendly fuel.

The scientific research is directed towards defining of optimisation systems, such as the use of treatments prior to the anaerobic process, in order to enhance its yields, especially in terms of biogas production. 
Moreover, the possibility to recover hydrogen from OFMSW anaerobic digestion in order to use it as an energy source, additional to methane.

Finally, interesting aspect to be studied, especially in relation to wet systems, is the use of reactor supernatants for the growth of particular microalgae used in specific industrial application.

\section{Acknowledgement}

The study was partly funded by the University of Salerno (FARB - ex 60\%).

\section{References}

[1] De Gioannis G., Muntoni A., Cappai G., Milia S. Landfill gas generation after mechanical biological treatment of municipal solid waste. Estimation of gas generation rate constants. Waste Management, 29, 1026-1034, 2009.

[2] Fricke K., Santen H., Rainer W., Hüttner A., Dichtl N. Operating problems in anaerobic digestion plants resulting from nitrogen in MSW. Waste Management, 27, 30-43, 2007.

[3] Poh P.E., Chong M.F. Development of anaerobic digestion methods for palm oil mill effluent (POME) treatment. Bioresource Technology, 100, 19, 2009.

[4] Nguyen P.H.L., Kuruparan, P., Visvanathan, C. Anaerobic digestion of municipal solid waste as a treatment prior to landfill. Bioresource Technology 98 (2), 380-387, 2007.

[5] Bouallagui H., Touhami Y., BenCheikh R., Hamdi M. Bioreactor performance in anaerobic digestion of fruit and vegetable wastes. Process Biochemistry 40 (3-4), 989-995, 2005.

[6] Rao M.S., Singh S.P. Bioenergy conversion studies of organic fraction of MSW: kinetic studies and gas yield-organic loading relationships for process optimization. Bioresource Technology 95 (2), 173-185, 2004.

[7] Gallert C., Henning A., Winter J. Scale-up of anaerobic of the biowaste fraction from domestic wastes. Water Research 37 (6), 433-1441, 2003.

[8] Charles W., Walker L., Cord-Ruwisch R. Effect of pre-aeration and inoculum on the start-up of batch thermophilic anaerobic digestion of municipal solid waste. Bioresource Technology 100 (8), 2329-2335, 2009.

[9] Davidsson Å., Gruvberger C., Christensen T.H., Hansen T.L., Jansen J.L.C. Methane yield in the source-sorted organic fraction of municipal solid waste. Waste Management 27 (3), 406-414, 2007.

[10] Lopez Torres M., Espinosa Lloréns M. Effect of alkaline pretreatment on anaerobic digestion of solid wastes. Waste Management 28, 2229-2234, 2008.

[11] Dewil R., Appels L., Baeyens J., Degrève J. Peroxidation enhances the biogas production in the anaerobic digestion of biosolids. Journal of Hazardous Materials 146, 577-581, 2007. 
[12] Fox M., Noike T. Wet oxidation pretreatment for the increase in anaerobic biodegradability of newspaper waste. Bioresource Technology 91, 273-281, 2004.

[13] Weemaes M., Grootaerd H., Simoens F., Verstraete W. Anaerobic digestion of ozonized biosolids. Water Research 34 (8), 2330-2336, 2000.

[14] Valladão A., Freire D., Cammarota M. Enzymatic pre-hydrolysis to the anaerobic treatment of effluents from poultry slaughterhouses. International Biodeterioration \& Biodegradation 60, 219-225, 2007.

[15] Bougrier C., Delgenès J.P., Carrère H. Impacts of thermal pre-treatments on the semi-continuous anaerobic digestion of waste activated sludge. Biochemical Engineering Journal 34, 20-27, 2007.

[16] Carrère H., Sialve B., Bernet N. Improving pig manure conversion into biogas by thermal and thermo-chemical pretreatments. Bioresource Technology 100, 3690-3694, 2009.

[17] Naddeo V., Cesaro A., Amodio V., Belgiorno V. Anaerobic co-digestion of municipal solid waste with ultrasound pretreatment. Proc. of the $1^{\text {st }}$ Int. Conf. On Environmental Science and Technology, edsT.D. Lekkas, Global NEST,: Chania, Crete, 3-6 September 2009.

[18] Chen L., Li B., Li D., Gan J., Kitamura Y. Ultrasound-assisted hydrolysis and acidogenesis of solid organic wastes in a rotational drum fermentation system. Bioresource Technology 99, 8337-8343, 2008.

[19] Hartmann H., Angelidaki I., Ahrin B.K. Co-digestion of the organic fraction of municipal waste with other waste types. Biomethanization of the organic fraction of municipal solid waste-IWA Publishing, 2003.

[20] De Baere L. Will anaerobic digestion of solid waste survive in the future? Water, Science and Technology 53 (8), 187-194, 2006.

[21] Schievano A., D’Imporzano G., Malagutti L., Fragali E., Ruboni G., Adani F. Evaluating inhibition conditions in high-solids anaerobic digestion of organic fraction of municipal solid waste. In press on Bioresource Technology, 2010.

[22] Source separated organic materials anaerobic digestion. Feasibility study. Report by Foth Infrastructure and Environment, LCC, 2009.

[23] Lissens G., Vandevivere P., De Baere L., Biey E.M., Verstraete W. Solid waste digestors: process performance and practice for municipal solid waste digestion. waste. Water Science and Technology, 44, 91-102, 2001.

[24] Themelis N.J. Anaerobic digestion of biodegradable organics in municipal solid wastes. Submitted in partial fulfilment of the requirements for Master of Science Degree in Earth Resources Engineering, 2002.

[25] ROS Roca International www.rosroca.com

[26] Bozano Gadolfi P. La valorizzazione della frazione organica dei rifiuti e delle biomasse con la tecnologia di digestione anaerobica BTA. Tecnologie e prospettive della produzione di energia da biomasse, 2006.

[27] Monsal www.monsal.com 
[28] Bungay S. Operational experience of advanced anaerobic digestion. $14^{\text {th }}$ European bio-solids and organic resources conference and exhibition, 2009.

[29] Oleszkiewicz J.A., Poggi-Varaldo. High solids anaerobic digestion of mixed municipal and industrial wastes. Journal of Environmental Engineering 123, 1087-1092, 1997.

[30] Bolzonella D., Pavan P., Mace S., Cecchi F. Dry anaerobic digestion of differently sorted organic municipal solid waste: a full scale experience. Water Science and Technology, 53 (8), 23-32, 2006.

[31] Vandevivere P., De Baere L.,Verstraete W. Types of anaerobic digester for solid wastes. Biomethanization of the organic fraction of municipal solid waste-IWA Publishing, 2003.

[32] Piccinini S. La digestione anaerobica dei rifiuti organici ed altre biomasse: la situazione e le prospettive in Italia. Il Compostaggio di qualità, Arvan s.r.l. - ISBN 88-87801-08-8, 2003.

[33] Kirchmayr R., Mayer M., Braun R., Krismer M., Resch Ch. Anaerobic digestion of source sorted OFMSW and other co-substrates: status and experience in Austria. Biogas da frazioni organiche di rifiuti solidi urbani in miscela con altri substrati, 2007.

[34] Edelmann W. Anaerobic digestion of source separated OFMSW and other cosubstrates: status and experience in Switzerland. Biogas da frazioni organiche di rifiuti solidi urbani in miscela con altri substrati, 2007.

[35] Fruteau De Laclos H., Desbois S., Saint-Joly C. Anaerobic digestion of municipal solid organic waste: Valorga full-scale plant in Tilburg, the Netherlands. Water Science and Technology 36 (6-7), 457-462, 1997.

[36] California Integrated Waste Management Board. Current Anaerobic Digestion Technologies Used for Treatment of Municipal Organic Solid Waste. March 2008.

[37] Confalonieri A. La digestione anaerobica dei rifiuti urbani in Europa:un'indagine di settore, 2009. 